\title{
LANDSLIDE DETECTION AND CHARACTERIZATION USING TERRESTRIAL 3D LASER SCANNING (LIDAR)
}

\author{
Mehmet Volkan OZDOGAN * and Ahmet Hamdi DELIORMANLI
}

Dokuz Eylul University, Department of Mining Engineering, Adatepe Mah. Dogus Cad. No: 207-I 35390 Buca Izmir, Turkey

*Corresponding author's e-mail: mehmet.ozdogan@deu.edu.tr

\begin{tabular}{|c|c|}
\hline ARTICLE INFO & \\
\hline & ABSTRACT \\
\hline Article history: & \multirow{6}{*}{$\begin{array}{l}\text { Landslides are one of the most common hazards in open pit mines. The occurrence of a landslide } \\
\text { affects both the safety and economy of the pits. By understanding the movement mechanism of } \\
\text { the slopes, preventative safety studies can be undertaken. The determination of the orientation of } \\
\text { a landslide is the most important step to understand the movement mechanism in open pit mines. } \\
\text { The dip and the dip direction of a slope give significant information about the orientation of } \\
\text { a landslide, traditionally measured by compass. This study presents an approach to determine the } \\
\text { landslide movement orientation and slope deformation rate by using a 3D terrestrial laser } \\
\text { scanner. A landslide on the north-east of the Simav open pit where is located at the west region } \\
\text { of Turkey, known as the Kucuk Hill landslide, was examined as a case study. The orientation of } \\
\text { the slopes was found and contour graphs were drawn. Then, stereographic projection results } \\
\text { showed the orientation of the landslide. On the other hand, a monitoring scenario was revealed } \\
\text { and the deformations on the pit benches were determined. }\end{array}$} \\
\hline $\begin{array}{l}\text { Received } 23 \text { April } 2019 \\
\text { Accepted } 25 \text { August } 2019 \\
\text { Available online } 10 \text { October } 2019\end{array}$ & \\
\hline Keywords: & \\
\hline Landslide & \\
\hline Monitoring & \\
\hline Terrestrial laser scanner & \\
\hline
\end{tabular}

\section{INTRODUCTION}

Landslides are a ground movement phenomenon and include debris or earth slipping down a slope, rock falls, or failure of slopes under the influence of gravity. Natural causes and mining activities can both cause instability in open pit mines (Werner and Friedman, 2009).

Presently, various monitoring techniques are available to predict landslide risks and to detect the slope failures (Lynn and Bobrowsky, 2008). Inclinometers, piezometers and extensometers are well-known geotechnical instruments which have been using for landslide monitoring. Usually, these systems need cable based communication between the instruments applied on slope and a computer (Singer and Thuro, 2006). However, geotechnical monitoring instruments with cable have some disadvantages such as, high operation cost, the limited distance for communication and frequent maintenance requirement (Garcia et al., 2010). Remote sensing is a viable alternative technology to overcome these limitations.

Currently, many remote sensing technologies are currently available to evaluate slope stability and monitor slopes for landslide hazards. These technologies can be classified into three groups. The first group includes the visual interpretation of stereoscopic aerial photographs by employing the characteristics of optical remote sensing. Many researchers (Chandler and Cooper, 1989; Chandler and Moore, 1989: Chandler and Brunsden, 1995; Soeters and Van Westen, 1996; Mantovani et al.,
1996; Baum et al., 1998; Parise, 2003; Van Westen and Getahun, 2003; Walstra et al., 2007; Kasperski et al., 2010a; Yeh et. al., 2011; Guerriero et al., 2013; Fernández, et al., 2015; Peppa et al., 2016) have carried out aerial photography based studies to understand the evolution of landslides.

Another remote sensing technology that can be used for surface monitoring is real-time kinematic (RTK) global positioning system (GPS) technique. The researchers who used GPS for monitoring landslides reported that they reached highly accurate results in their surface monitoring studies. (Josep et al., 2000; Gili et al., 2000; Malet et. al., 2002; Coe et al., 2003; Squarzoni et al., 2005; Peyret et al., 2008; Rawat et al., 2011; Wang, 2011; Guerriero et.al., 2016; Guerriero et.al., 2017; Mirzaee et. al., 2017; Guerriero et.al., 2018).

The latest remote sensing technique used for monitoring landslides are analysing of innovative remote sensing products, such as synthetic aperture radar images, high-spatial-resolution multispectral images, digital elevation models (DEMs) obtained from space or airborne sensors (Guzzetti et al., 2000; Metternicht et al., 2005; Colesanti and Wasowski, 2006; Ardizzone et al., 2007; Cascini et al., 2009; Cascini et al., 2013; Tantianuparp et al., 2013; Tang et al., 2015; Huang et al., 2017), very-high-resolution satellite images (Nichol and Wong, 2005; Stumpf and Kerle, 2011; Ozdogan and Deliormanli, 2016; Stumpf et at., 2017) and laser scanners (Light Detection of Ranging system - LiDAR). 
In recent years, LiDAR techniques have been applied to monitor landslide areas. The application of LiDAR techniques in geodesic measurements is relatively new; however, it has been progressing rapidly. There are two LiDAR techniques that have been developed, differing through the position of the equipment employed. These techniques are airbornebased, Airborne Laser Scanning (ALS) and groundbased, Terrestrial Laser Scanning (TLS). The data obtained from ALS and TLS are called point clouds.

Up to now, an increasing number of studies have been published that discuss the use of LiDAR in landslide studies. These studies are common concern with monitoring, modelling and mapping of landslides (Derron and Jaboyedoff, 2010). Some researchers carried out LiDAR for the characterization and monitoring of landslides outside risk mapping. However, TLS provides high precision data for modelling the study area, especially when the topography of the study area is complex and poor DEM is available (Rowlands et al., 2003; Corsini et al., 2009; Dunning et al., 2009; Jaboyedoff et al., 2009a; Jaboyedoff et al., 2009b; Jaboyedoff et al., 2010).

In this study, landslide detection and characterization using terrestrial 3D laser scanning are presented for an open pit mine. Specifically, the concept of the research is to calculate the orientation of a landslide using the three-point problem together with point-cloud data obtained from TLS. Three points that were not collinear or close to being collinear on slope faces were selected to be calculated for the orientation of a landslide. The orientation of the slope faces was calculated using the Cramer's Rule method based on the three-point problem. Calculated orientations were analysed on the stereonet as a dip and dip direction. The direction of the landslide was determined using the results of this analysis. This method can be used effectively to determine the orientation of landslide movement in mining areas in a short time. In addition, monitoring of slope movements by a cloud comparison method was performed. Furthermore, a 2D slope stability analysis was carried out for the open pit mine and production plan of the pit was revised based on the orientation of the landslide obtain from TLS measurements.

\section{STUDY SITE}

Simav open pit mine in Bigadic was used for the case study. Bigadic is located in the west of Turkey. The study area is an important and well-known site for borate production in Turkey. The Bigadic borates were formed in two different zones separated by a thick tuff unit, elongated in a northeast-southwest direction. The basin is limited on the east and west by extensive volcanic and on the northwest by the basement complex. Neogene sediments of the Bigadic volcano-sedimentary basin were deposited in a number of individual or interconnected basins bordered by extensive outcrops of basement rocks. In addition, these basins trend northeast-southwest and they may have been formed at the beginning of the Neogene.

The lateral variation in the thickness of the Neogene sediments probably reflects deposition either in separate perennial lakes or in an interconnected chain of lakes. The sediments, including the borate deposits, have been moderately folded and faulted. The total thickness of the Neogene sequence exceeds $1,200 \mathrm{~m}$. The lower and upper borate zones vary in thickness between 35 to 130 and 20 to $110 \mathrm{~m}$, respectively as shown in Figure 1 (Helvac1, 1995).

All the stress cracks, faults and other discontinuities in the landslide area were studied on the map of engineering geology in Figure 2. Faults with small and large pulses in different characters were mapped in the study area. The F1, F2, F9 and F10 faults F1, F2, F3 and F4 are parallel / approximately parallel to each other in the direction of

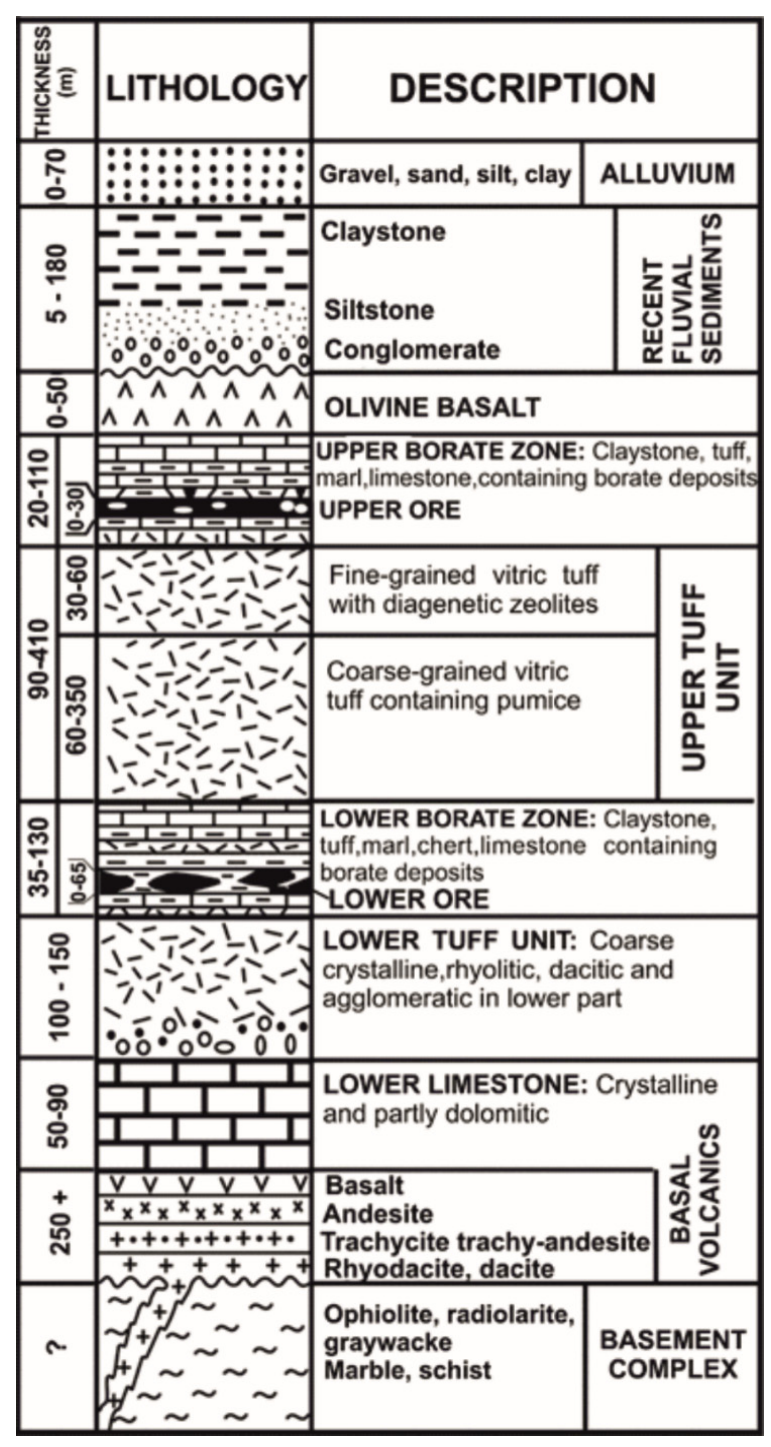

Fig. 1 Stratigraphy of the Bigadic Borate Deposits (Helvac1, 1995). 

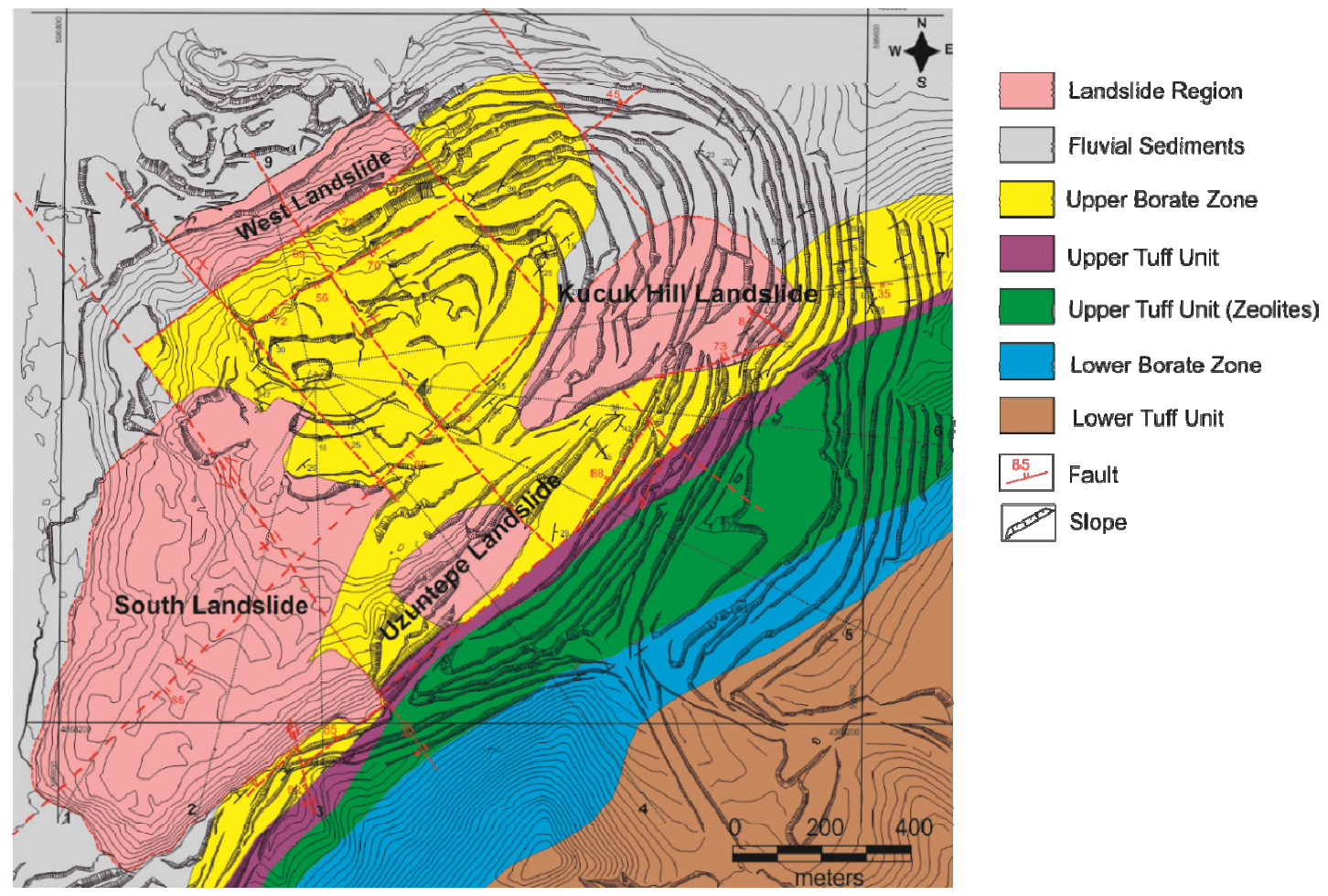

Fig. 2 Landslide zones in Simav open pit mine area.

Table 1 The orientations of discontinuities in open pit mine.

\begin{tabular}{cccccc}
\hline Dip & Dip Direction & Type & Dip & Dip Direction & Type \\
\hline 70 & 147 & Fault 1 & 65 & 232 & Joint set 1 \\
68 & 337 & Fault 2 & 38 & 255 & Joint set 2 \\
45 & 311 & Fault 3 & 70 & 215 & Joint set 3 \\
71 & 322 & Fault 4 & 10 & 53 & Joint set 4 \\
62 & 265 & Fault 5 & 26 & 127 & Joint set 5 \\
78 & 55 & Fault 6 & 89 & 280 & Joint set 6 \\
90 & 229 & Fault 7 & 20 & 120 & Joint set 7 \\
65 & 234 & Fault 8 & 43 & 180 & Joint set 8 \\
60 & 132 & Fault 9 & 58 & 140 & Joint set 9 \\
67 & 145 & Fault 10 & & & \\
\hline
\end{tabular}

the open pit in the direction of SW-NE. F5, F6, F7, F8, F9 and F10 faults are similar to the F1-4 faults and parallel to each other in the direction of NW-SE direction parallel to the open pit mine (Fig. 2). The average orientation of discontinuities in the area is tabulated in Table 1.

In the field, the mining operation method is an open pit. Open pit operations include drilling, blasting, and excavation activities. The overall wall slope angle of the open pit mine is $20^{\circ}$ with an interramp slope angle of about $25^{\circ}$ and a bench height of $10 \mathrm{~m}$. The production direction is north-east and ten fault zones are observed in the study area. Figure 2 gives the landslide map of Simav open pit mine. Four landslides regions are shown in the open pit mine area highlighted in pink. They are known as the West, Kucuk Hill, Uzun Hill, and South landslides. In this study, the Kucuk Hill landslide bearing significant cracks was investigated. In the Kucuk Hill landslide area, due to the mass movement from the northeast to the southwest, a creep zone occurred reaching the borate zone and a flow zone appeared reaching the upper step of the open pit floor. The cracks observed in the Kucuk Hill Landslide area are $3-65 \mathrm{~cm}$ wide and have a visible depth of 2.00-2.50 meters. Figure 3 shows a view from the Kucuk Hill landslide.

\section{METHODOLOGY}

\subsection{LIDAR SCANS}

A Leica Scan Station II scanner was used to acquire LiDAR scans. The scanner has a dual window system that covers a $360^{\circ}$ horizontal and $270^{\circ}$ vertical field of view. A resolution scan of about 5 by $5 \mathrm{~mm}$ was used in the point-cloud data acquisition. For each station, the scanning distance was about $300 \mathrm{~m}$ for this resolution. Before scanning, optical images obtained from the scanner were recorded so that the measured points could be coloured with an image colour that most closely related to each scanned point. The pointcloud data generated from the scanner is a set of point 


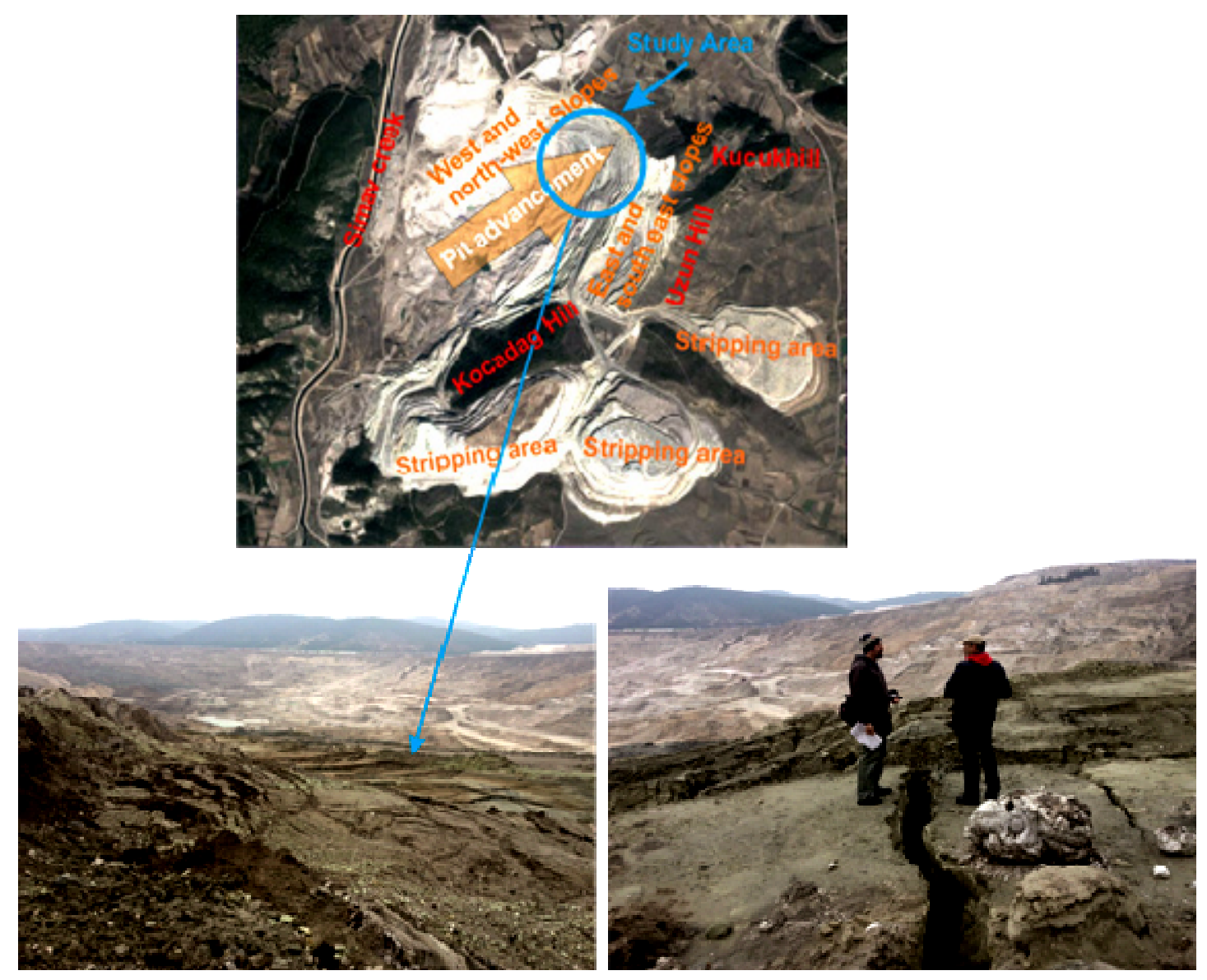

Fig. 3 View from the Kucuk Hill landslide.

defined by $\mathrm{x}, \mathrm{y}$, and $\mathrm{z}$ coordinates. The $\mathrm{z}$ coordinates are always vertical, assuming that the scanner was always correctly levelled. The $\mathrm{x}$ and $\mathrm{y}$ axes were orientated with the coordinate system of the scanner. The point-cloud data obtained from the LiDAR scanner were processed using Leica Geosystems HDS Cyclone software. The software, including the functional modules, provides a wide set of work process options for LiDAR scanning. The software performs a crucial role in handling and in viewing high-definition point clouds effectively and aids in the fast extraction of deliverables.

The procedure for monitoring and determining displacements of a slope using LiDAR is as follows:

- Planning of scan area;

- Point-cloud data acquisition;

- Point-cloud data processing (registration and merging data); and

- Evaluation of point-cloud with three-point data method for determining the orientation of landslide and point cloud comparison method for determining the displacements.

Because of the topographical structure of the slope, various scan distances, and the incidence angles of the laser beam, the point-cloud data taken from the scan area is heterogeneously distributed. Therefore, to guarantee the maximum coverage and accuracy, the determination of the number and optimal locations of the scanning station is very important. In this study, to reduce the shadow-masked zone and to enlarge the acquisition area, three on-site stations along the slope were selected (Fig. 4).

The data acquisition and processing steps include the determination of the scan resolution, registration, merging data, and geo-referencing. The distance of the LiDAR acquisition did not exceed $300 \mathrm{~m}$. The monitored slopes were free of vegetation. Three HDS targets for each scan were used for registering, merging, and geo-referencing the point cloud. These HDS targets were scanned individually after scanning of the slope. $20 \mathrm{~mm}$ vertical and $20 \mathrm{~mm}$ horizontal resolution at a distance of $300 \mathrm{~m}$ were applied to the target scans. The detection of targets in the point cloud could be done automatically, and the registration of each point cloud was carried out perfectly. The root mean square error in registration varied between $1.8 \mathrm{~mm}-3.0 \mathrm{~mm}$ over all registrations. In the study, the real-time kinematic mode of the Leica C25 GPS has been used to access the coordinates of the HDS targets and for georeferencing the merged point cloud.

\subsection{THEORY/CALCULATION}

The case study area of the research is an open pit mine. Due to the risk of a landslide in the pit, the mine operation was stopped. In order to restart production at the mine site, the landslide needs to be characterized quickly. Determining the current situation of the landslide plays an important role in the 


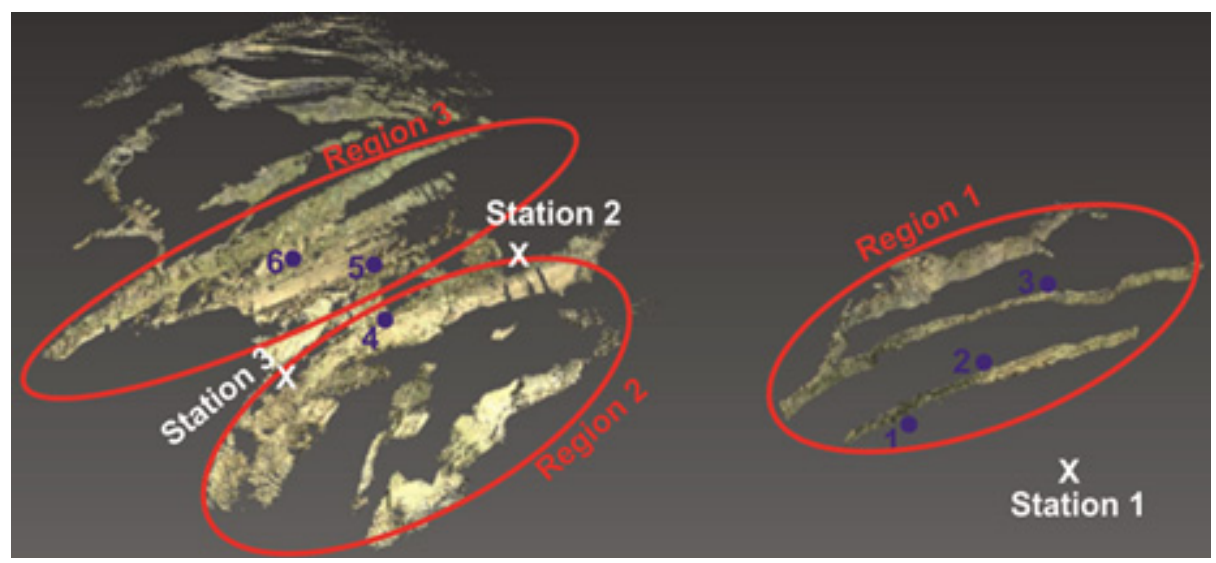

Fig. 4 Positions of scanner and targets in the study area (Blue dots indicate the targets. The targets 4, 5 and 6 were used for both scans from station 2 and station 3 ).

planning of the mine for production again. Remote sensing methods, in particular, TLS method, provide fast and reliable data for the determination and monitoring of landslides. However, TLS alone is not a sufficient method for defining the landslide. To understand landslide phenomena, it is also necessary to reconstruct the depth structures integrating the necessary depth data (inclinometers, seismic, etc.). The present landslide is active. It is confirmed with the condition of the study area shown in Figure 3. Due to cracks and stability problems caused by landslides, delineation of the landslide mechanism was not possible to be measured by classical methods (inclinometers, seismic etc.). Moreover, the study area is dangerous. Therefore, the use of terrestrial laser has been seen as the best alternative to determine the mechanism of the landslide.

In this paper, two methods were used for monitoring landslide hazards, with the data taken from a terrestrial laser scanner. The aim of the first method was to determine the orientation of the landslide. There are a number of methods available for determining the orientation of a landslide, as a strike and dip without manual measurement. The three-point data method is well known and is based on an analytical expression that can be easily solved using computer software.

In this study, the dip and dip direction of the slope faces were calculated using Cramer's rule method and the three-point problem. Figure 5 shows the definition of the three-dimensions of three noncollinear points. The plane is represented by the equation:

The equations for the straight lines in each of each coordinate plane can be derived for three independent variables at a time be zero as follows:

$$
\begin{aligned}
& a x+b y+c z+d=0 \\
& a x+c z+d=0 \\
& b y+c z+d=0 \\
& a x+b y+d=0
\end{aligned}
$$

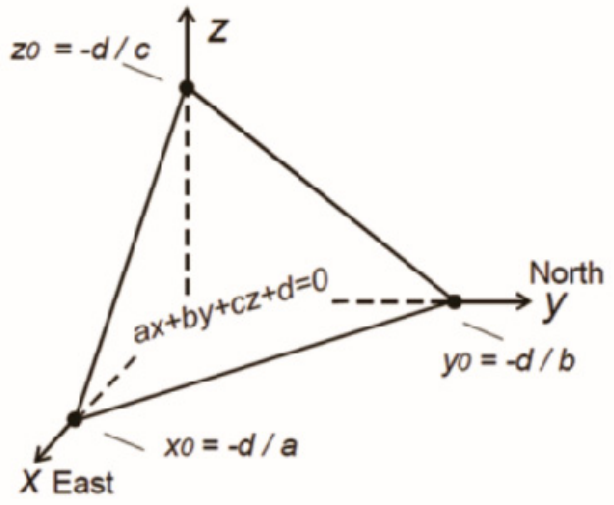

Fig. 5 The equation of a plane in linear-coefficient for three-point problem.

The xy plane is horizontal. Therefore, equation 4 can be defined as the equation of a line of strike. Therefore, the azimuth of strike ( $\theta$ strike) is calculated as the arctangent of the slope of this line.

$$
\theta_{\text {strike }}=\arctan \frac{\partial x}{\partial y}=\arctan \left(-\frac{b}{a}\right)
$$

When the $\partial z / \partial x$ the slope of the $x z$ section is the tangent of the dip in the east direction, $\partial z / \partial y$ the slope of the yz section is the tangent of the dip in the north direction. The two partial derivatives $(\partial z / \partial x$ and $\partial \mathrm{z} / \partial \mathrm{y})$ are used to calculate the true dip using the mathematical notion of the gradient. Thus, the vector gradient $\left(\overline{\mathrm{V}}_{z}\right)$ is described as follow:

$$
\begin{aligned}
& \left|\overline{\mathrm{V}}_{z}\right|=\sqrt{\left(\frac{\partial z}{\partial x}\right)^{2}+\left(\frac{\partial z}{\partial y}\right)^{2}} \\
& \theta_{\text {dip }}=\arctan \left[\sqrt{\frac{a^{2}+b^{2}}{c_{2}}}\right]
\end{aligned}
$$

The aim of the second method is to determine the deformation on pit benches. Point to point comparison, the DEM comparison, and cloud to mesh 
distance comparison methods are the most common methods applied for determining topographic changes (Abellán et al., 2006; Antoine et al., 1987; Bauer et al., 2005; Bitelli et al., 2004; Prokop and Panholzer, 2009; Kasperski et al., 2010b). Recently, due to some deficiencies in the existing comparison methods, a Multiscale Model to Model Cloud Comparison (M3C2) algorithm to detect the spatial difference between a two point-cloud has also been proposed (Lague et al., 2013).

The M3C2 algorithm can be explained with accurate orthogonal distance measurements between two point-cloud data. It differs from the other methods given above by using the matching of homologous parts to yield a displacement field. It is capable of making 24 distance measurements in 3D. Roughness is a key component, which can be measured and utilized at each stage of the computation for the M3C2 algorithm. The overall roughness can be regionally characterized at a scale reliable with the nearby roughness. Regional averaging around each point also diminishes the impact of the surface roughness. The M3C2 utilizes a regional measure of the cloud roughness and point density to predict a parametric confidence interval and a test for the statistical importance of the measured changes.

First of all, the M3C2 algorithm is explained simply in two stages. Regarding the simple configuration, the initial stage is the calculation of normal, N, around a core point, I, at a scale of D. First, $\mathrm{N}$ is estimated from cloud number 1 . Then, the scale, over which the cloud is most planar, is chosen. In the second stage; the intersection of the reference point cloud data and the compared point clouds with a cylinder having a diameter of $d$ and axes of $(i, N)$ characterizes 2 sub-clouds. Every single sub-cloud is reflected on the cylinder axis that comprises the distribution of the distances along the normal direction. They are useful in determining the median position of every single cloud, which is i1 and i2. After that process, the local point-cloud roughness $\sigma_{1}(\mathrm{~d})$ and $\sigma_{2}(\mathrm{~d})$ and size $\mathrm{n} 1$ and $\mathrm{n} 2$ of the 2 sub-clouds are needed to predict a local confidence interval. Subsequently, the M3C2 algorithm was applied to a complicated topography. As for rough surfaces, the normal is measured at an extremely small scale when compared to the roughness characteristics (D1), and its orientation inevitably shows considerable variation. This situation will lead to the overestimation of the distance measured between two clouds. In this case, it is seen that a larger scale of D2 outputs a more homogenous normal orientation. The following distance computation takes the form of the average orthogonal distance between cloud 1 and 2 .

In the scope of this study, in order to reveal the deformation of pit benches, TLS data were taken over two different days and was evaluated by the $\mathrm{M} 3 \mathrm{C} 2$ method. For Multiscale Model to Model Claud Comparison analysis (M3C2), subsample parameter was chosen as core points.

\section{RESULTS AND DISCUSSIONS}

LiDAR measurements were carried out at three stations on the eastern slopes of the mine, with two stations on the stage elevation of 102 and one stations at an elevation of $33 \mathrm{~m}$. The elevation of $33 \mathrm{~m}$ is the base elevation of the mine whereas the elevation of $102 \mathrm{~m}$ is located in the middle elevations of the Kucuk Hill landslide area. These elevations provide the most suitable scanning range for measuring the landslide zone by TLS. In addition, the safest surfaces in the mine are located at these elevations. The study area was scanned twice within 30 days. Monitoring of the landslide was evaluated in comparison with LiDAR (TLS) point-cloud data taken on two dates.

Orientations of some slopes were measured manually with a geological compass in the study field. The measurements for each slope were recorded in a survey notebook. The measurements were used for cross-validation of the LiDAR measurements. The manual measurements were identified in Tables 2, 3 and 4 .

Using the cyclone software viewer module, three individual points on the slope face were selected for a measurement. The faces were selected from three different regions homogeneously. These regions have shown on point cloud data in Figure 4. For each region, the slope faces were divided into areas of approximately 30 meters in length using point cloud data. Then these faces were numbered. It is important that each selected surface has point cloud data from both TLS measurements. The points were spread out as far as possible on the same slope face and care was taken to ensure that the three points were not collinear or close to being collinear. The selected slope face was numbered and, then, the three data points were listed in data sheet software for each slope face. The dip and dip direction of the slope faces were calculated using the Cramer's Rule method and the three-point problem (Eqs: 5, 7). The calculated results were evaluated using the stereographic based method with DIPS 6.0 software for determining the orientation of the landslide.

Table 2 gives the results of the orientation of the selected slope faces at an elevation of $33 \mathrm{~m}$. Orientations of the landslide are given on a lower hemisphere stereographic projection plot image in Figure 6; the first measurement was shown green and the second was shown in blue. According to the stereographic projection results, the orientation of the landslide was found to be 54/215 (in a dip and dipdirection notation).

Table 3 gives the results of the orientation calculation of the selected slope faces at an elevation of $102 \mathrm{~m}$. Twenty faces were selected and their orientations were calculated. The orientations of the landslide were shown on a lower hemisphere stereographic projection plot image in Figure 7; the first measurement was shown in green and the second was shown in blue. The orientation of the landslide was found to be $31 / 204$ (in a dip and dip-direction notation). 
Table 2 The results of the orientation of selected slope faces at an elevation of $33 \mathrm{~m}$, calculated using Cramer's Rule method and the three-point problem (Data in parentheses are manual measurements with a geological compass).

\begin{tabular}{cccccc}
\hline Face & East & North & Elevation & Dip & Dip Direction \\
\hline 1 & 597860.8 & 4369069.3 & 36.4 & $52(51)$ & $187(189)$ \\
2 & 597860.6 & 4369069.0 & 36.6 & 59 & 195 \\
3 & 597904.5 & 4369071.2 & 45.1 & 62 & 202 \\
4 & 597904.0 & 4369070.9 & 44.9 & 63 & 203 \\
5 & 597877.7 & 4369019.0 & 45.6 & 46 & 52 \\
6 & 597877.6 & 4369019.8 & 45.2 & 43 & 201 \\
7 & 597904.5 & 4369017.6 & 53.3 & 54 & 211 \\
8 & 597903.1 & 4369017.8 & 53.1 & 58 & 212 \\
9 & 597792.1 & 4368970.5 & 35.9 & 59 & 217 \\
10 & 597792.1 & 4368969.6 & 36.1 & 66 & 220 \\
11 & 597840.7 & 4368968.7 & 45.3 & 61 & 216 \\
12 & 597841.4 & 4368969.7 & 44.7 & $43(41)$ & 214 \\
13 & 597877.4 & 4368969.6 & 54.4 & 73 & $212(208)$ \\
14 & 597875.9 & 4368970.0 & 53.8 & 70 & 242 \\
15 & 597786.9 & 4368921.3 & 43.4 & 50 & 238 \\
16 & 597786.9 & 4368920.9 & 43.5 & 51 & 209 \\
17 & 597843.2 & 4368919.5 & 54.3 & 42 & 212 \\
18 & 597844.0 & 4368920.2 & 54.4 & 43 & 236 \\
19 & 597746.6 & 4368870.7 & 45.8 & 51 & 234 \\
20 & 597747.6 & 4368870.8 & 45.6 & 54 & 224 \\
21 & 597821.7 & 4368871.4 & 55.3 & 55.4 &
\end{tabular}

Table 3 The results of the orientation of the selected slope faces at an elevation of $102 \mathrm{~m}$, calculated using Cramer's Rule method and the three-point problem (Data in parentheses are manual measurements with a geological compass).

\begin{tabular}{rccccc}
\hline \multicolumn{1}{c}{ Face } & East & North & Elevation & Dip & Dip Direction \\
\hline 1 & 598142.0 & 4369284.9 & 89.6 & 4 & 114 \\
2 & 598142.9 & 4369285.0 & 89.5 & 4 & 117 \\
3 & 598067.2 & 4369288.3 & 75.6 & 4 & 70 \\
4 & 598067.9 & 4369286.7 & 75.5 & 4 & 67 \\
5 & 598183.3 & 4369232.1 & 98.8 & 38 & 173 \\
6 & 598181.7 & 4369231.5 & 97.7 & 38 & 183 \\
7 & 598177.2 & 4369240.7 & 95.7 & 4 & 105 \\
8 & 598177.3 & 4369240.8 & 95.5 & $7(10)$ & $142(140)$ \\
9 & 598152.3 & 4369234.9 & 88.2 & 8 & 137 \\
10 & 598151.9 & 4369235.2 & 88.2 & 2 & 334 \\
11 & 598059.3 & 4369234.7 & 76.2 & 2 & 274 \\
12 & 598059.7 & 4369234.6 & 76.3 & 3 & 45 \\
13 & 598125.7 & 4369184.3 & 87.4 & 4 & 40 \\
14 & 598124.7 & 4369185.3 & 87.3 & 4 & 88 \\
15 & 598043.0 & 4369183.9 & 75.4 & 19 & 235 \\
16 & 598041.2 & 4369184.4 & 75.3 & $25(23)$ & $230(229)$ \\
17 & 598130.8 & 4369138.8 & 92.4 & 6 & 45 \\
18 & 598128.6 & 4369137.1 & 93.0 & 5 & 42 \\
19 & 598089.9 & 4369135.8 & 85.5 & 85.3 & \\
20 & 598088.6 & 4369137.3 & & 36 \\
\hline
\end{tabular}

Table 3 gives the results of the orientation calculation of the selected slope faces at an elevation of $102 \mathrm{~m}$. Twenty faces were selected and their orientations were calculated. The orientations of the landslide were shown on a lower hemisphere stereographic projection plot image in Figure 7; the first measurement was shown in green and the second was shown in blue. The orientation of the landslide was found to be $31 / 204$ (in a dip and dip-direction notation).

At an elevation of 102 upper, the calculated results of the orientation of the selected slopes are 


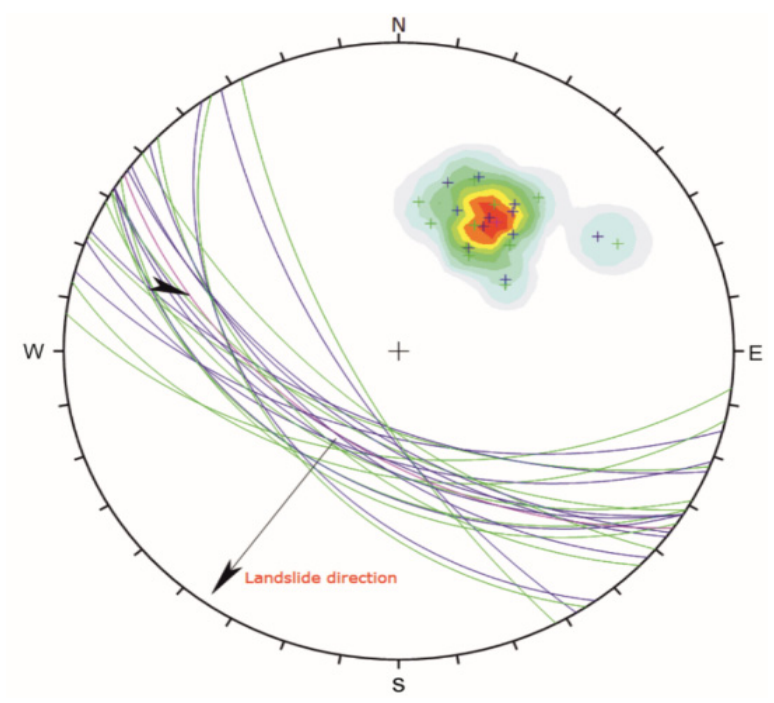

Fig. 6 Contour graph for the elevation of $33 \mathrm{~m}$. (Green; first measurement, blue; second measurement) (Dips 6.0).

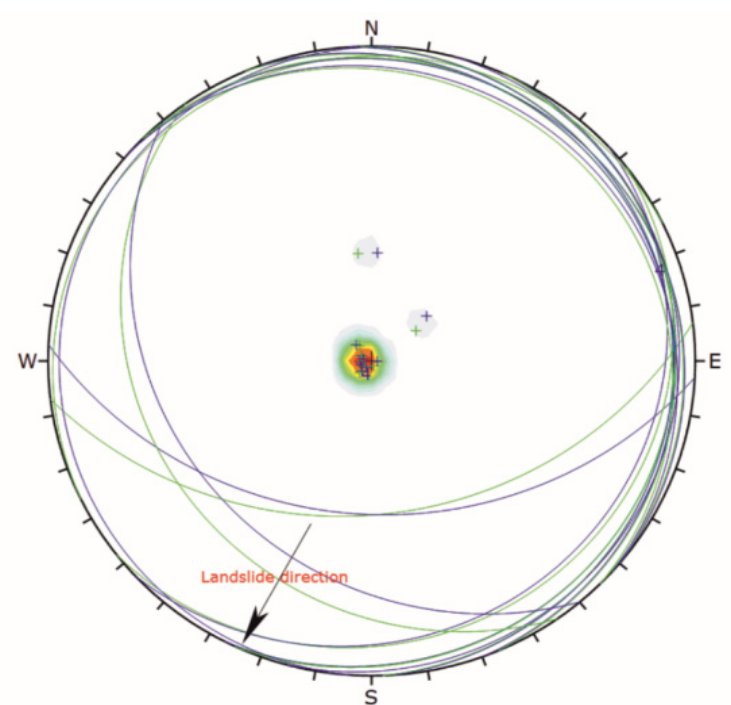

Fig. 7 Contour graph for the elevation of $102 \mathrm{~m}$. (Green; first measurement, blue; second measurement) (Dips 6.0).

Table 4 The results of the orientation of selected slope faces of at an elevation of $102 \mathrm{~m}$ upper calculated using Cramer's Rule method and the three-point problem 2 (Data in parentheses are manual measurements with a geological compass).

\begin{tabular}{cccrrr}
\hline Face & East & North & Elevation & Dip & Dip Direction \\
\hline 1 & 598273.1 & 4369331.7 & 116.3 & 57 & 177 \\
2 & 598274.8 & 4369331.0 & 116.4 & 58 & 180 \\
3 & 598269.6 & 4369283.6 & 116.9 & 47 & 196 \\
4 & 598269.7 & 4369281.7 & 116.4 & $51(50)$ & $199(195)$ \\
5 & 598250.4 & 4369231.4 & 105.1 & 36 & 198 \\
6 & 598250.2 & 4369230.7 & 105.2 & 36 & 197 \\
7 & 598225.7 & 4369236.1 & 102.0 & 26 & 157 \\
8 & 598224.8 & 4369236.1 & 101.7 & 26 & 164 \\
9 & 598210.5 & 4369235.3 & 101.8 & 5 & 92 \\
10 & 598209.5 & 4369235.3 & 101.7 & 5 & 96 \\
11 & 598204.1 & 4369232.6 & 101.5 & 3 & 129 \\
12 & 598203.8 & 4369231.5 & 101.3 & 3 & 114 \\
13 & 598272.1 & 4369178.0 & 112.2 & 46 & 180 \\
14 & 598270.6 & 4369178.0 & 112.0 & 48 & 196 \\
15 & 598235.5 & 4369178.2 & 105.1 & 41 & 87 \\
16 & 598234.2 & 4369178.1 & 105.1 & 41 & $230(234)$ \\
17 & 598184.9 & 4369180.1 & 98.5 & $31(30)$ & 229 \\
18 & 598335.8 & 4369136.3 & 129.1 & 29 & 202 \\
19 & 598333.1 & 4369134.4 & 128.8 & 36 & 201 \\
20 & 598221.3 & 4369132.6 & 103.4 & 36 & 204 \\
21 & 598219.2 & 4369132.7 & 103.3 & 43 & 240 \\
22 & 598194.5 & 4369132.3 & 98.2 & 42 & 241 \\
23 & 598192.4 & 4369132.8 & 98.2 & 49 & 211 \\
24 & 598309.4 & 4369082.4 & 135.2 & 47 & 206 \\
25 & 598309.1 & 4369082.3 & 135.3 & 38 & \\
26 & 598236.7 & 4369080.0 & 110.8 & 39 & \\
27 & 598238.7 & 4369083.5 & 112.9 & & \\
\hline
\end{tabular}

presented in Table 4. The orientation of the landslide was determined using the lower hemisphere stereographic projection plot image in Figure 8; the orientation of the landslide was 40/202 (in a dip and dip-direction notation).

Results of the lower hemisphere stereographic projections show that the average landslide direction is about 207 for the study area. The Kucuk Hill landslide direction is southwest. The slope angle is about 42 (42/207 in a dip and dip-direction notation). The direction of the mining production at Kucuk Hill field is northeast. In other words, the landslide and the mining production are on the same line, but the directions are different. 


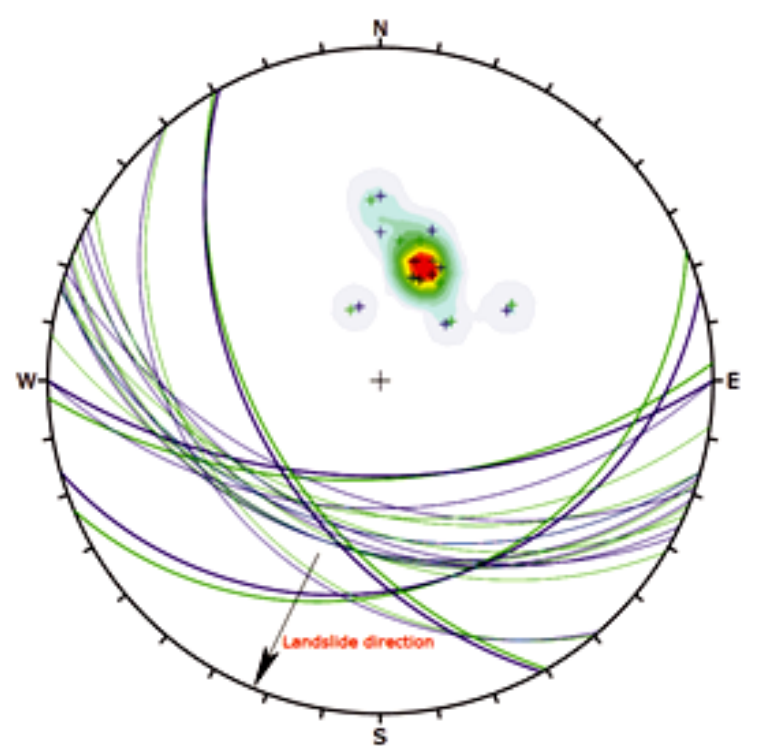

Fig. 8 Contour graph for the elevation of upper 102 $\mathrm{m}$. (Green; first measurement, blue; second measurement) (Dips 6.0).
The M3C2 study was carried out to determine the deformation on the slope surface by means of a CloudCompare3D point cloud and mesh processing software which is an open-source project. In the study, the point cloud created from the first scan was accepted as the reference point cloud and the following were compared with that reference point cloud. The magnitude of the displacements analyzed by the M3C2 algorithm is shown in Figures 9-10. The frequency of each magnitude of displacement is given by means of a histogram.

According to the $\mathrm{M} 3 \mathrm{C} 2$ analysis, the pit slopes have deformed toward the front of the slope. Then the slopes have slid downward. The analyses show that this movement characteristic has probably been repeated continuously. The histogram data in Figure 9 and Figure 10 clearly shows that $98 \%$ of the total displacement is between $+750 \mathrm{~mm}$ and $-750 \mathrm{~mm}$ at an elevation of $33 \mathrm{~m}$ over a 30 -day period. About $95 \%$ of the positive and negative displacements detected from the TLS measurements are from $+1500 \mathrm{~mm}$ to $-750 \mathrm{~mm}$ over the same period at an elevation of $102 \mathrm{~m}$ base and upper.

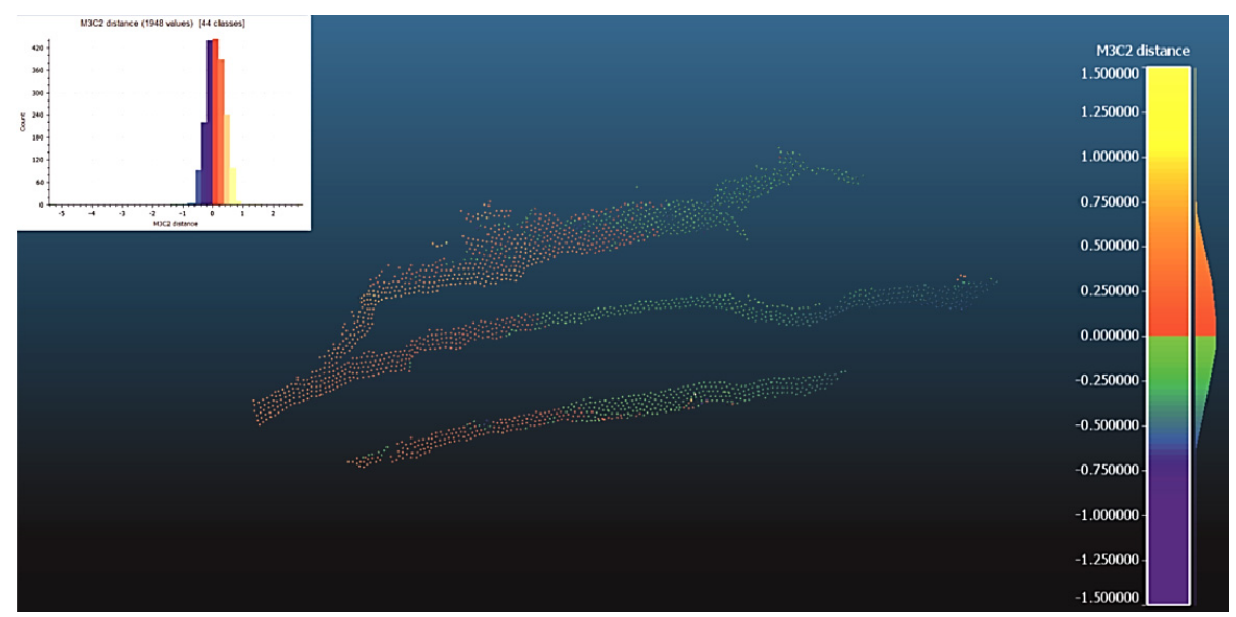

Fig. 9 M3C2 analysis between the first and second scan, and a histogram is showing the magnitude of displacements at elevation $33 \mathrm{~m}$. (CloudCompare3D).
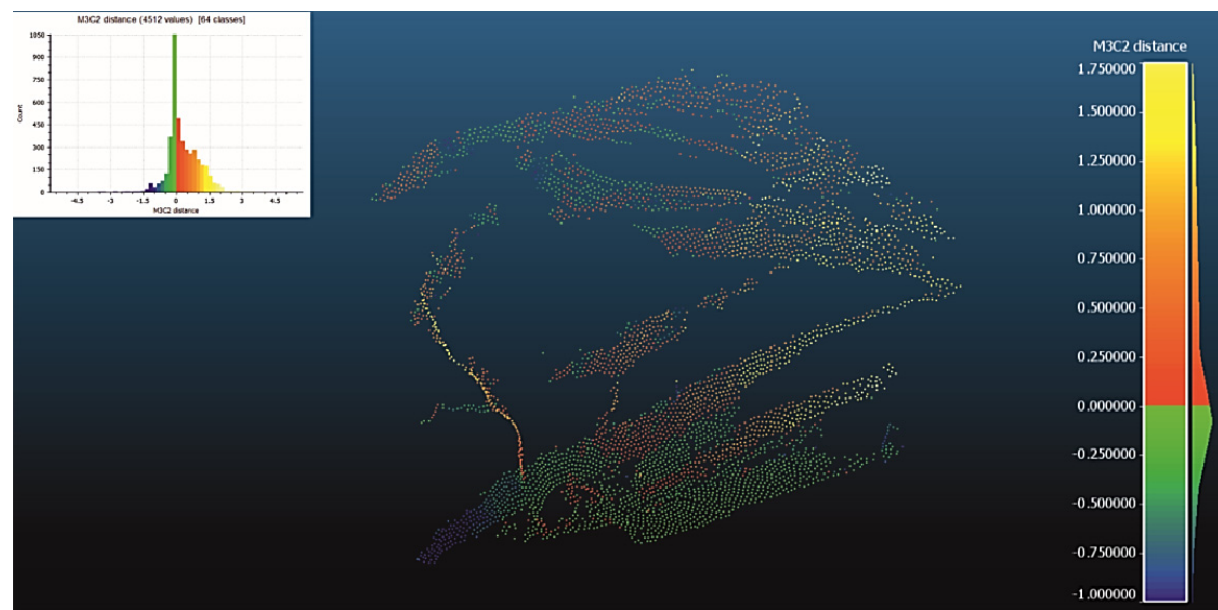

Fig. $10 \mathrm{M} 3 \mathrm{C} 2$ analysis between the first and second scan and a histogram is showing the magnitude of displacements at elevation $102 \mathrm{~m}$ base and upper. (CloudCompare3D). 

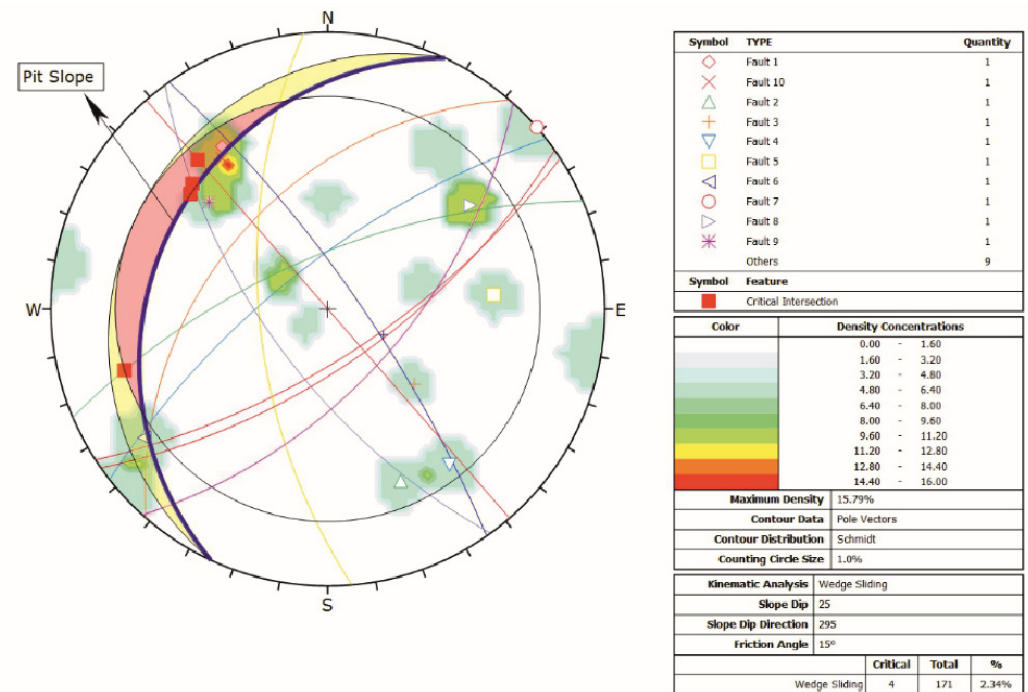

Fig. 11 Wedge sliding analysis for the pit operation, showing four critical possibilities of wedge sliding at $25^{\circ}$ inter-ramp slope angle at lower elevations in open pit mine. (Dips Software 6.0).

The slopes of Kucuk Hill field in the open pit are the high faces with the highest elevation difference in the open pit and the discontinuities in this region are controlled by the location of the organic clays located within the limestone levels at lower elevations. Watersaturated plastic clays in Figure 1 played an important role in the Kucuk Hill landslide. Internal parameters of clay, such as cohesion and internal friction angle values, are reduced with the surface-water flow. In the study, clay samples were collected from the field and the internal parameters such as cohesion (c) $0.12 \mathrm{MPa}$, and friction angle $(\varnothing) 15^{\circ}$ were determined. According to the open pit design parameters, the overall wall slope angle is $20^{\circ}$ and the inter-ramp slope angle is about $25^{\circ}$ especially in the lower elevations of Kucuk Hill landslide area. In case interramp angles reach up to $25^{\circ}$, the wedge-shaped discontinuities demonstrated in the kinematic analysis in Figure 11 occurring at lower elevations depending on the partial bevel angles cause deformations at the top until they reach an equilibrium state. This was the main reason for the Kucuk Hill landslide.

Given the slope geometry and discontinuity orientation, a kinematic analysis determines whether and where a particular instability mechanism is kinematically possible (Goodman and Bray, 1976; Hoek and Bray, 1981; Hudson and Harrison, 1997; Matheson, 1989). The kinematic analysis investigates various instability mechanisms: plane failure, wedge failure, block toppling and flexural toppling. The kinematic stability analyses were executed on stereographic projection images using Dips 6.0 designed by Rocscience in Figure 11. According to the wedge kinematic analysis results in Figure 11, four intersection points are shown in the primary critical zone for wedge failure. Even though the percentage of critical intersections compared to the total number is actually very low (about 2.4\%) it is big enough to start the landslide movement in the Kucuk Hill landslide region. Therefore wedge sliding is a concern for this slope orientation.
Inter-ramp slope angles have a determinant role in Kucuk Hill region from the aspect of slope stability. Slide 6.0 software was used for the slope stability analyses. Non-circular surface type of stability analyses was carried out in the study. The region in which the open pit is located poses seismically active character. For this reason, additional loads that would be induced by earthquakes were also integrated into analyses. By using earthquake accelerations, excess dynamic loads were added to the block on the sliding surface. The data used in the analysis were utilized by taking basis the study of Erdik et al. (1999, Global Seismic Hazard Assessment Program Report). In Figure 12 safety coefficients of inter-ramp slope angles regarding the faces of lower elevations, which are located in the excavation profile of Kucuk Hill, are given. As seen in the mentioned figures, safety coefficients happen to drop to 0.96 in inter-ramp slope angles.

Based on the results, the slope failure mechanisms in the study area were commonly caused by intense surface-water flow, due to heavy precipitation or rapid snow melt that erodes and mobilizes loose soil or rock on steep slopes. The area where the open pit mine is located generally experiences heavy rainfall in the winter seasons. In addition to this, the failure mechanism might have been triggered by rapid ground movement, caused by an earthquake or blasting. Drilling and blasting is a common excavation method used throughout the study area. For these reasons, during the winter season, the mining operation is at higher risk.

According to the results of kinematic and slope stability analysis, there is a mechanism that triggers the landslide at the lower elevations of the Kucuk Hill area. The LiDAR measurements support this phenomenon. It is observed that the landslide movement continued in the southwest direction by using three-point problem with data obtained from the LiDAR measurements. It means that The landslide movement continues in the opposite direction to the progression of the pit mine. 


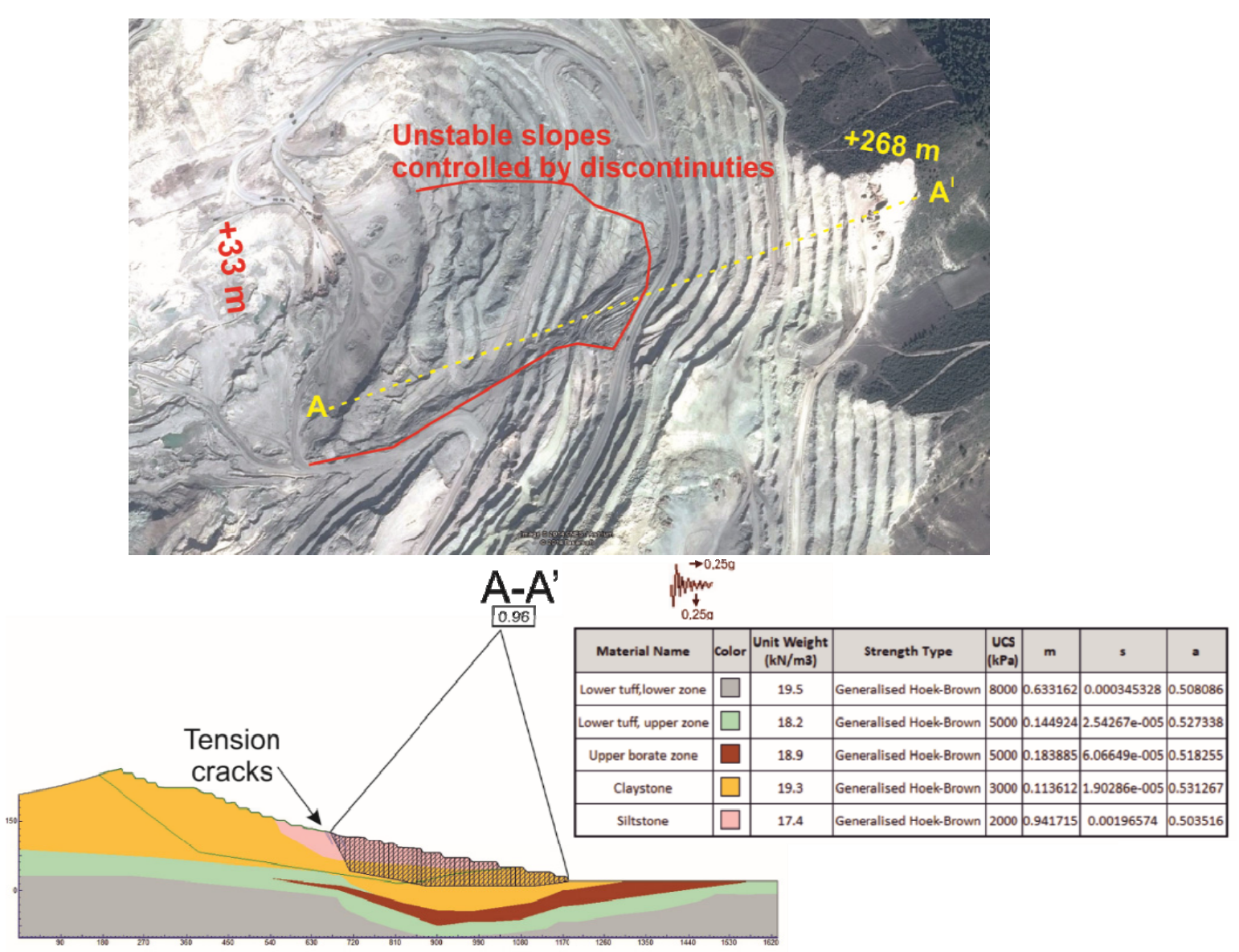

Fig. 12 Stability analysis at lower elevations in open pit mine (Slide 6.0).
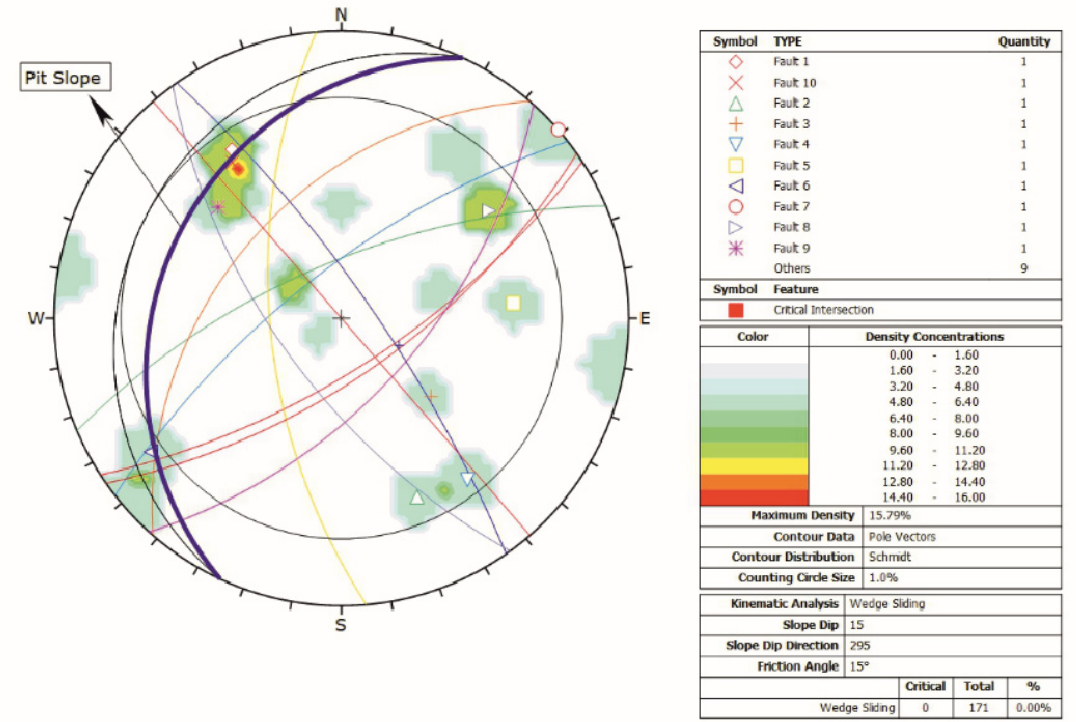

Fig. 13 Wedge sliding analysis for revised open pit mine planning, showing no critical possibility of wedge sliding at $15^{\circ}$ inter-ramp slope angle at lower elevations in open pit mine. (Dips Software 6.0).

In order to restore the stability of the mine, the mine plans must be revised. According to this, in the revised plans, a pillar was left into the $30 \mathrm{~m}$ hearth at $+20 \mathrm{~m}$ base level in Kucuk Hill region of the pit. In this case, in the revised plan, the inter ramp angle between $+20 \mathrm{~m}$ elevation and $+50 \mathrm{~m}$ elevation was reduced to $15^{\circ}$.

The results of wedge sliding kinematic analysis are shown in Figure 13. The results show that there is no possibility of wedge failure in the slope at lower elevations. The revised planning of open pit mine is given in Figure 14.

The results show that the use of terrestrial 3D laser scanning is one of the best ways to landslide detection and characterization. TLS ensure highquality data for modelling the landslide area, especially when the topography of the study field is complex. Furthermore, terrestrial 3D laser scanning is very effective remote sensing technology for monitoring small landslide areas especially occurring 


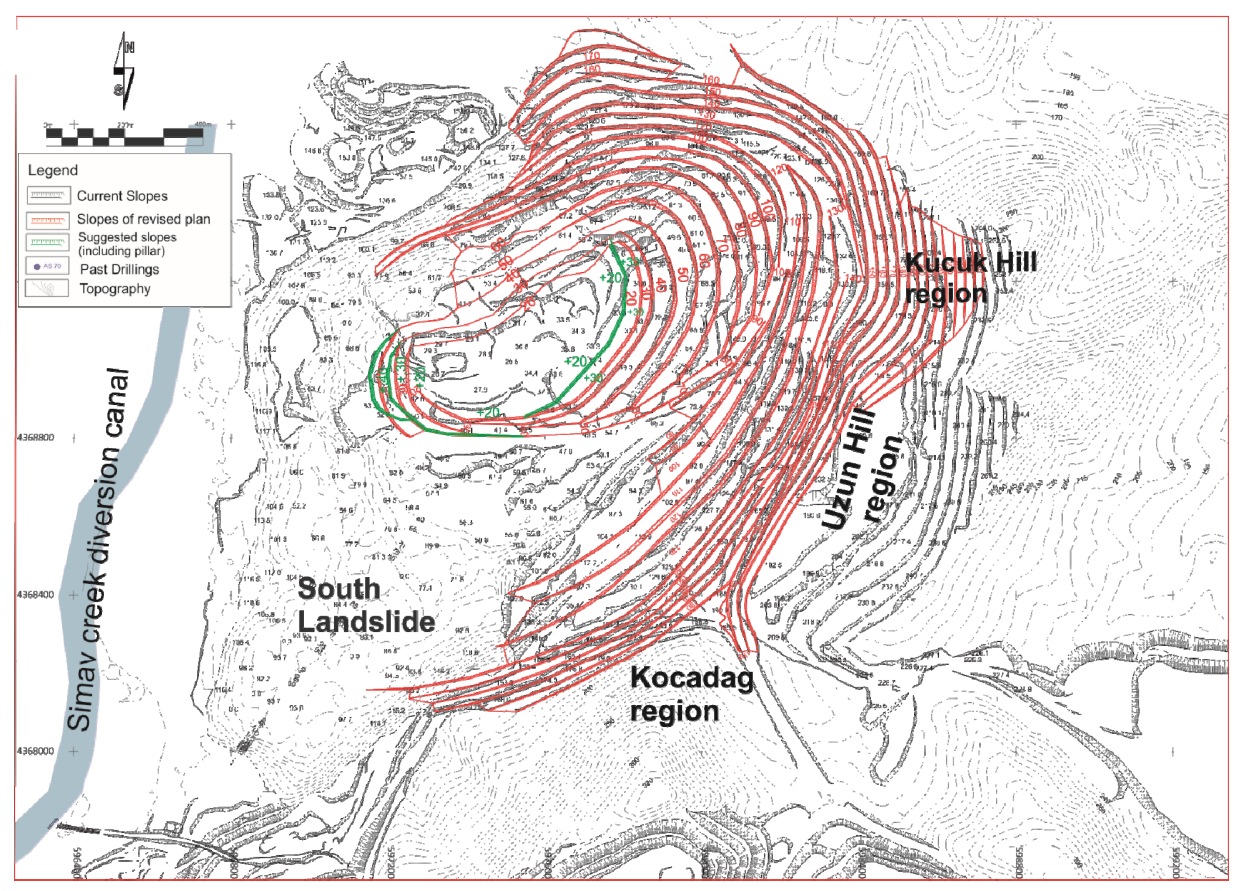

Fig. 14 The map of revised open pit mine planning.

in open pit mines. Another result in this study, the orientation of the landslide can be easily calculated with data obtained from the scanner using three-point problem method introduced in Figure 5. Moreover, cloud comparison method is a successful method to determine slope movements. Results obtained using all these methods can be used for input data of the replanning of open pit mine. This is also important for reducing the landslide effects.

\section{CONCLUSIONS}

The production rate and production direction have to be determined based on landslide characteristics. More effective and safe pit production is available by determining the orientation of the landslide, and landslide hazards in open pit mines can be avoided by taking precautions in good time. Regular examination and systematic monitoring of the landslide field are important for early detection of failure and any associated hazards. The results of this study show that the data obtained from LiDAR measurements were quick and easy to collect, and were also more accurate for monitoring and analysing landslides. There is a great opportunity to use this technology for monitoring and analysing landslides: the orientation of the landslide, and determining any landslide deformation.

\section{ACKNOWLEDGEMENTS}

This research was supported by Dokuz Eylul University, Engineering Faculty (Project no: $2012 \mathrm{~KB}$ FEN 61 and Project no: 2013 KB FEN 010) and Dokuz Eylul University, The Graduate School of Natural and Applied Sciences (Project no: 2011 KB FEN 12)

\section{REFERENCES}

Abellán, A., Vilaplana, J.M. and Martínez, J.: 2006, Application of a long-range terrestrial laser scanner to a detailed rockfall study at Vall de Núria (Eastern Pyrenees, Spain). Eng. Geol., 88, 136-148. DOI:10.1016/j.enggeo.2006.09.012

Antoine, P., Camporota, Pi, Giraud, A. and Rochet, L.: 1987, La menaced'écroulementaux Ruines de Séchilienne (Isère). Bulletin des laboratoires des Ponts et Chaussées, 150-151, 55-64.

Ardizzone, F., Cardinali, M., Galli, M., Guzzetti, F. and Reichenbach, P.: 2007, Identification and mapping of recent rainfall-induced landslides using elevation data collected by airborne Lidar. Nat. Hazards Earth Syst. Sci., 7, 637-650. DOI: 10.5194/nhess-7-637-2007

Baum, R.L., Messerich, J. and Fleming, R.W.: 1998, Surface deformation as a guide to kinematics and three-dimensional shape of slow-moving, clay-rich landslides, Honolulu, Hawaii. Environ. Eng. Geosci., 4, 3, 283-306.

Bauer, A., Paar, G. and Kaltenbock, A.: 2005, Mass movement monitoring using Terrestrial Laser Scanner for rock fall management. Geo-information for Disaster Management, Springer, 393-406. DOI: $10.1007 / 3-540-27468-5$ _28

Bitelli, G., Dubbini, M. and Zanutta, A.: 2004, Terrestrial laser scanning and digital photogrammetry techniques to monitor landslide bodies. Proceedings of the 20th ISPRS Congress Geo-Imagery Bridging Continents, Istanbul, Turkey, July 12-23, 2004. ISPRS Archives, $35,5,246-251$.

Cascini, L., Fornaro, G. and Peduto, D.: 2009, Analysis at medium scale of low-resolution DInSAR data in slowmoving landslide-affected areas. ISPRS J. Photogramm. Remote Sens., 64, 6, 598-611. DOI: 10.1016/j.isprsiprs.2009.05.003

Cascini, L., Peduto, D., Pisciotta, G., Arena, L., Ferlisi, S. and Fornaro, G.: 2013, The combination of DInSAR and facility damage data for the updating of slowmoving landslide inventory maps at medium scale. Nat. Hazards Earth Syst. Sci., 13, 1527-1549.

DOI: $10.5194 /$ nhess-13-1527-2013 
Chandler, J.H. and Cooper, M.A.R.: 1989, The extraction of positional data from historical photographs and their application to geomorphology. Photogramm. Rec., 13, 73, 69-78. DOI: 10.1111/j.1477-9730.1989.tb00647.x

Chandler, J.H. and Moore, R.: 1989, Analytical photogrammetry: a method for monitoring slope instability. Q. J. Eng. Geol., 22, 97-110.

DOI: 10.1144/GSL.QJEG.1989.022.02.02

Chandler, J.H. and Brunsden, D.: 1995, Steady state behaviour of the Black Ven mudslide: the application of archival analytical photogrammetry to studies of landform change. Earth Surf. Process. Landf., 20, 3, 255-275. DOI: 10.1002/esp.3290200307

Coe, J.A., Ellis, W.L., Godt, J.W., Savage, W.Z., Savage, J.E., Michael, J.A., Kibler, J.D., Powers, P.S., Lidke, D.J. and Debray, S.: 2003, Seasonal movement of the Slumgullion landslide determined from Global Positioning System surveys and field instrumentation, July 1998--March 2002. Eng. Geol., 68, 1-2, 67-101. DOI: 10.1016/S0013-7952(02)00199-0

Colesanti, C. and Wasowski, J.: 2006, Investigating landslides with spaceborne Synthetic Aperture Radar (SAR) interferometry. Eng. Geol., 88, 3, 173-199. DOI: $10.1016 / j$.enggeo.2006.09.013

CloudCompare 3D V2.9 3D point cloud and mesh processing software Open Source Project. https://www.danielgm.net/cc/

Corsini, A., Cervi, F., Daehne, A., Ronchetti, F. and Borgatti, L.: 2009, Coupling geomorphic field observation and LIDAR derivatives to map complex landslides. In: Malet, J.P., Remaitre, A. and Bogaard, T. (Eds.), Landslides processes-from geomorphologic mapping to dynamic modelling. Proceedings of Landslide Processes Conference, February 2009, Strasbourg, 6-7.

Derron, M.H. and Jaboyedoff, M.: 2010, Preface to the special issue. In: LIDAR and DEM techniques for landslides monitoring and characterization. Nat. Hazards Earth Syst. Sci., 10, 1877-1879. DOI: $10.5194 /$ nhess-10-1877-2010

DIPS 6.0 Rocscience Software

Dunning, S., Massey, C. and Rosser, N.: 2009, Structural and geomorphological features of landslides in the Bhutan Himalaya derived from terrestrial laser scanning. Geomorphology, 103, 17-29. DOI:10.1016/ j.geomorph.2008.04.013

Erdik, M., Biro, Y.A., Onur, T., Sesetyan, K. and Birgoren, G.: 1999, Assessment of earthquake hazard in Turkey and neighboring regions. Global Seismic Hazard Assessment Program Report.

Fernández, T., Pérezac, J.L., Cardenalac, F.J., Lópeza, A., Gómeza, J.M., Colomoa, C., Delgado, J. and Sánchez, M.: 2015, Use of a light UAV and photogrammetric techniques to study the evolution of a landslide in Jaén (Southern Spain). Int. Arch. Photogramm Remote Sens. Spatial Inf. Sci., XL-3/W, 3241-3248.

DOI: 10.5194/isprsarchives-XL-3-W3-241-2015

Garcia, A., Hördt, A. and Fabian, M.: 2010, Landslide monitoring with high resolution tilt measurements at the Dollendorfer Hardt landslide, Germany. Geomorphology, 120, 1-2, 16-25.

DOI: 10.1016/j.geomorph.2009.09.011

Gili, J.A., Corominas, J. and Rius, J.: 2000, Using Global Positioning System techniques in landslide monitoring. Eng. Geol., 55, 3, 67-192. DOI: 10.1016/S0013-7952(99)00127-1

Goodman, R.E. and Bray, J.: 1976, Toppling of rock slopes. Proceedings Speciality Conference on Rock
Engineering for Foundations and Slopes, Boulder, 2, 201-234.

Guerrieroa, L., Revellinoa, P., Coeb, J.A., Focaretac, M., Grellea, G., Albanesed, V., Corazzad, A. and Guadagno, F.M.: 2013, Multi-temporal maps of the Montaguto Earth flow in Southern Italy from 1954 to 2010. J. Maps, 9, 1, 135-145, DOI: $10.1080 / 17445647.2013 .765812$

Guerriero, L., Revellino, P., Luongo, A., Focareta, M., Grelle, G. and Guadagno, F.M.: 2016, The Mount Pizzuto earth flow: deformational pattern and recent thrusting evolution. J. Maps, 12, 5, 1187-1194. DOI: $10.1080 / 17445647.2016 .1145150$

Guerriero, L., Bertello, L., Cardozo, N., Berti, M., Grelle, G. and Revellino, P.: 2017, Unsteady sediment discharge in earth flows: A case study from the Mount Pizzuto earth flow, southern Italy. Geomorphology, 295, 260 284. DOI: 10.1016/j.geomorph.2017.07.011

Guerriero, L., Guadagno, F.M. and Revellino, P.: 2018, Estimation of earth-slide displacement from GPSbased surface-structure geometry reconstruction. Landslides, 16, 2, 425-430.

DOI: $10.1007 / \mathrm{s} 10346-018-1091-0$

Guzzetti, F., Cardinali, M., Reichenbach, P. and Carrara, A.: 2010, Comparing landslide maps: A case study in the Upper Tiber River Basin, Central Italy. Environ. Manage., 25, 3, 247-263. DOI: $10.1007 / \mathrm{s} 002679910020$

Helvac1, C.: 1995 Stratigraphy, mineralogy and genesis of the Bigadic borate deposits, Western Turkey. Econ. Geol., 90, 5, 1237-1260.

DOI: $10.2113 /$ gsecongeo.90.5.1237

Hoek, E. and Bray, J.W.: 1981, Rock slope engineering. Revised 3rd Edition, The Institution of Mining and Metallurgy, London, 341-351.

Huang, J., Xie, M., Farooq, A. and Williams, E.J.: 2017, DInSAR technique for slow-moving landslide monitoring based on slope units. Surv. Rev., 51, 364, 1-8. DOI: 10.1080/00396265.2017.1380947

Hudson, J.A. and Harrison, J.P.: 1997, Engineering rock mechanics: An introduction to the principles. Published by Elsevier Science, London.

ISRM: 2007, The complete ISRM suggested methods for rocks characterization, testing and monitoring: 19742006. Ulusay, R. and Hudson, J.A. (Eds.). Compilation arranged by the ISRM Turkish national group, Ankara, Turkey, 628 pp.

Jaboyedoff, M., Oppikofer, T., Abellán, A., Derron, M.H., Loye, A., Metzger, R. and Pedrazzini, A.: 2010, Use of LIDAR in landslide investigations: a review. Nat. Hazards, 61, 1, 5-28.

DOI: $10.1007 / \mathrm{s} 11069-010-9634-2$

Jaboyedoff, M., Oppikofer, T., Locat, A., Locat, J., Turmel, D., Robitaille, D., Demers, D. and Locat, P.: 2009a, Use of ground-based LIDAR for the analysis of retrogressive landslides in sensitive clay and of rotational landslides in river banks. Can. Geotech. J., 46, 1379-1390. DOI: 10.1139/T09-073

Jaboyedoff, M., Pedrazzini, A., Loye, A., Oppikofer, T., Güell i Pons, M. and Locati, J.: 2009b, Earth flow in a complex geological environment: the example of Pont Bourquin, Les Diablerets (Western Switzerland). In: Malet, J.P., Remaitre, A. and Bogaard, T. (Eds.): Landslides processes-from geomorphologic mapping to dynamic modelling. Proceedings of the landslide processes conference, 6-7 February 2009, Strasbourg, France. 
Josep, A.G., Jordi, C. and Joan, R.: 2000, Using Global Positioning System Techniques in landslide monitoring. Eng. Geol., 55, 3, 167-192.

DOI: 10.1016/S0013-7952(99)00127-1

Kasperski, J., Delacourt, C., Allemand, P and Potherat, P.: 2010a, Evolution of the Sedrun landslide (Graubünden, Switzerland) with ortho-rectified air images. Bull. Eng. Geol. Env. 69, 421-430.

Kasperski, J., Delacourt, C., Allemand, P., Potherat, P., Jaud, M., Varrel, E.: 2010b, Application of a Terrestrial Laser Scanner (TLS) to the study of the Séchilienne Landslide (Isère, France). Remote Sens., 2, 2785-2802. DOI: 10.3390/rs122785

Lague, D., Brodu, N. and Leroux, J.: 2013, Accurate 3D comparison of complex topography with terrestrial laser scanner: Application to the Rangitikei canyon (N-Z). ISPRS J. Photogramm. Remote Sens., 82, 1026. DOI: $10.1016 /$ j.isprsjprs.2013.04.009

Lynn, M. and Bobrowsky, P.: 2008, The landslide handbook - A guide to understanding landslides. Reston, Virginia, U.S. Geological Survey.

Malet, J.P., Maquaire, O. and Calais, E.: 2002, The use of Global Positioning System techniques for the continuous monitoring of landslides: application to the Super-Sauze earthflow (Alpes-de-Haute-Provence, France). Geomorphology, 43, 1-2, 33-54. DOI: $10.1016 / \mathrm{S} 0169-555 \mathrm{X}(01) 00098-8$

Mantovani, F., Soeters, R. and Van Westen, C.J.: 1996, Remote sensing techniques for landslide studies and hazard zonation in Europe. Geomorphology, 15, 3-4, 213-225. DOI: 10.1016/0169-555X(95)00071-C

Matheson, G.D.: 1989, The collection and use of field discontinuity data in rock slope design. Q. J. Eng. Geol., 22, 19-30.

Metternicht, G., Hurni, L. and Gogu, R.: 2005, Remote sensing of landslides: An analysis of the potential contribution to geo-spatial systems for hazard assessment in mountainous environments. Remote Sens. Environ., 98, 2, 284-303. DOI: $10.1016 /$ j.rse.2005.08.004

Mirzaee, S., Motagh, M. and Akbari, B.: 2017, Landslide monitoring using Insar Time-Series and GPS observations, case study: Shabkola Landslide in Northern Iran. Int. Arch. Photogramm Remote Sens. Spatial Inf. Sci., XLII-1/W1, 487-492. DOI: 10.5194/isprs-archives-XLII-1-W1-487-2017

Nichol, J. and Wong, W.S.: 2005, Detection and interpretation of landslides using satellite images. Land Degrad. Dev., 16, 3, 243-255. DOI: $10.1002 / \mathrm{ldr} .648$

Ozdogan, M.V. and Deliormanli, A.H.: 2016, Monitoring of landslide at Tuncbilek Open Pit Stripping Area with Terrestrial Laser Scanner and Optical Images. IOP Conf. Ser. Earth and Environ. Sci., 44, 4, 042035. DOI: $10.1088 / 1755-1315 / 44 / 4 / 042035$

Parise, M.: 2003, Observation of surface features on an active landslide, and implications for understanding its history of movement. Nat. Hazard Earth Sys. Sci., 3, 569-580. DOI: 10.5194/nhess-3-569-2003

Peppa, M.V., Mills, J.P., Moore, P., Miller, P.E. and Chambers, E.: 2016, Accuracy assessment of a UAVbased landslide monitoring system. Int. Arch. Photogramm Remote Sens. Spatial Inf. Sci., XLI-B5, 895-902.

DOI: 10.5194/isprs-archives-XLI-B5-895-2016

Peyret, M., Djamour, Y., Rizza, M., Ritz, J.F., Hurtrez, J.E., Goudarzi, M.A., Nankali, H., Chery, J., Le Dortz, K. and Uri, F.: 2008, Monitoring of the large slow
Kahrod landslide in Alboz mountain range (Iran) by GPS and SAR interferometry. Eng. Geol., 100, 3-4, 131-141. DOI: 10.1016/j.enggeo.2008.02.013

Prokop, A. and Panholzer, H.: 2009, Assessing the capability of terrestrial scanning for monitoring slow moving landslides. Nat. Hazard Earth Syst. Sci., 9, 1921-1928. DOI: 10.5194/nhess-9-1921-2009

Rawat, M.S., Joshi, V., Rawat, B.S. and Kumar, K.: 2011, Landslide movement monitoring using GPS technology: A case study of Bakthang landslide, Gangtok, East Sikkim, India. J. Dev. Agric. Econ., 3, $5,194-200$

Rowlands, K.A., Jones, L.D. and Whitworth, M.: 2003, Landslide laser scanning: a new look at an old problem. Q. J. Eng. Geol. Hydrogeol., 36, 155-157. DOI:10.1144/1470-9236/2003-08

Slide V 6.0. Rocscience 2D limit equilibrium slope stability software

Stumpf, A. and Kerle, N.: 2011, Object-oriented mapping of landslides using Random Forests. Remote Sens. Environ., 115, 10, 2564-2577. DOI: $10.1016 /$ j.rse.2011.05.013

Stumpf, A., Malet, J.P. and Delacourt, C.: 2017, Correlation of satellite image time-series for the detection and monitoring of slow-moving landslides. Remote Sens. Environ., 189, 40-55. DOI:10.1016/j.rse.2016.11.007

Soeters, R. and Van Westen, C.J.: 1996, Slope instability recognition, analysis and zonation. In: Turner, A.K. and Schuster, R.L. (Eds.), Landslides: Investigation and Mitigation. Spec. Report No. 247, National Academy Press, Washington DC, 129-177.

Squarzoni, C., Delacourt, C. and Allemand, P.: 2005, Differential single-frequency GPS monitoring of the La Valette landslide (French Apls). Eng. Geol., 79, 215-229. DOI: 10.1016/j.enggeo.2005.01.015

Tang, P., Chen, F., Guo, H., Tian, B., Wang, X. and Ishwaran, N.: 2015, Large-area landslides monitoring using advanced multi-temporal InSAR technique over the giant panda habitat, Sichuan, China. Remote Sens., 7, 7, 8925-8949. DOI: 10.3390/rs70708925

Tantianuparp, P., Shi, X., Zhang, L., Balz, T. and Liao, M.: 2013, Characterization of landslide deformations in three gorges area using multiple InSAR data stacks. Remote Sens., 5, 2704-2719. DOI: $10.3390 /$ rs 5062704

Van Westen, C.J. and Gethun, F.L.: 2003, Analyzing the evolution of the Tessina landslide using aerial photographs and digital elevation models. Geomorphology, 54, 1-2, 77-89. DOI: $10.1016 / \mathrm{S} 0169-555 \mathrm{X}(03) 00057-6$

Walstra, J., Chandler, J.H., Dixon, N. and Dijkstra, T.A.: 2007, Aerial photography and digital photogrammetry for landslide monitoring. Geological Society, London, Special Publications, 283, 53-63. DOI: $10.1144 / \mathrm{SP} 283.5$

Wang, G.: 2011, GPS landslide monitoring: Single base vs. network solutions - A case study based on the Puerto Rico and Virgin Islands Permanent GPS Network. J. Geod. Sci., 1, 3, 191-203. DOI: $10.2478 / \mathrm{v} 10156-010-0022-3$

Werner, E.D. and Friedman, H.P.: 2009, Landslides: Causes, types and effects. Natural Disaster Research, Prediction and Mitigation Series. Nova Science Publishers, UK

Yeh, M.L., Hsiao, Y.C., Chen, Y.H. and Chung, J.C.: 2011, A study on unmanned aerial vehicle applied to acquire terrain information of landslide. 32th Asian Conf. Remote Sensing, 3, 2210-2215. 